\title{
Antimicrobial resistance of Escherichia coli isolates from spray-chilled sheep carcasses during cooling
}

\author{
Resistencia antimicrobiana en aislados de Escherichia coli de canales de ovejas asperjadas durante la \\ refrigeración
}

\section{Resistência antimicrobiana de isolados de Escherichia coli de carcaças ovinas aspergidas durante o resfriamento}

\author{
Karina A Mateus $^{1 *}$ (D); Moisés R dos Santos ${ }^{1}$ (D); Jocelita de Limal ${ }^{1}$ (D) Lucine F de Bona ${ }^{2}$ (D); \\ Maria S T dos $\operatorname{Santos}^{2}$ (D); Arnildo Korb² ${ }^{\mathbb{D}}$; Jackeline K Kirinus ${ }^{1}$ (D); Julcemar D Kessler ${ }^{1}$ (D).
}

${ }^{1}$ Grupo de Pesquisa Produção, Carcaças e Carnes, Departamento de Zootecnia, Universidade do Estado de Santa Catarina, Chapecó, Brasil.
${ }^{2}$ Laboratório de Microbiologia, Departamento de Enfermagem, Universidade do Estado de Santa Catarina, Chapecó, Brasil.

To cite this article:

Mateus KA, dos Santos MR, de Lima J, de Bona LF, dos Santos MST, Korb A, Kirinus JK, Kessler JD. Antimicrobial resistance of Escherichia coli isolates from spray-chilled sheep carcasses during cooling. Rev Colomb Cienc Pecu 2021; 34(1):63-72. DOI: https://doi.org/10.17533/udea.rccp.v34n2a04

\begin{abstract}
Background: Multidrug-resistant bacteria present in food of animal origin raise human and animal health concerns. Objective: To assess antimicrobial resistance of Escherichia coli isolates from sheep carcasses subjected to spray-chilling with water (4 and 10 hours) during cooling. Methods: Thirty surface swabs were collected from carcasses before and after the last water spray in two slaughter periods. In a first assessment ( $1^{\text {st }}$ sampling), three spray-chilled carcasses (4 hours), three non-sprayed and one control carcass were sampled. In a second assessment ( $2^{\text {nd }}$ sampling), the same number of carcasses and treatments were maintained, but spray-chilling was extended to 10 hours. All samples collected were isolated and submitted to susceptibility test using $16\left(1^{\text {st }}\right.$ sampling $)$ and 17 ( $2^{\text {nd }}$ sampling $)$ antimicrobials, respectively. Results: Overall, E. coli isolates were resistant most antimicrobials. Spray-chilled and control carcasses (10 hours) showed resistance to meropenem. Conclusion: $E$. coli isolates from carcasses subjected to spray-chilling with water for 10 hours had higher antimicrobial resistance to one, two, and four antimicrobial classes, characterizing a multidrug resistance profile. These results highlight the need to monitor health status throughout the meat production processes.
\end{abstract}

Keywords: antimicrobial; antimicrobial resistance; antibiotic; bacterial resistance; carcass; enterobacteria; Escherichia coli; microbial resistance; multi-resistant organism; multidrog resistance; public health; sheep;slaughter; spray-chilled; spray-chilling.

Received: September 3, 2018; accepted: July 6, 2020

*Corresponding author. Rua Beloni Trombeta Zanin 680E - Bairro Santo Antônio - Chapecó - SC, Brasil, CEP: 89.815-630. E-mail: kazootecnista@gmail.com 


\section{Resumen}

Antecedentes: las bacterias multirresistentes presentes en alimentos de origen animal son motivo de alerta para la salud humana y animal. Objetivo: verificar la resistencia a antimicrobianos de aislados de Escherichia coli en canales ovinas sometidas a aspersión (4 y 10 h) durante la refrigeración. Métodos: Luego de dos faenas de sacrificio, treinta hisopos fueron colectados en la superficie de las canales antes y después de la última aspersión. En un primer sacrificio (1era colecta) se recolectaron muestras de tres canales sometidas a aspersión (4 horas), tres sin aspersión y una canal como control. En un segundo sacrificio (2da colecta), el mismo número de canales y tratamientos se mantuvo, y el período de aspersión se extendió a 10 horas. Las muestras recogidas fueron aisladas y sometidas a la prueba de susceptibilidad utilizándo 16 ( $1 .^{\text {a }}$ colecta) y 17 (2. ${ }^{\text {a }}$ colecta) antimicrobianos, respectivamente. Resultados: los aislamientos de E. coli fueron, en general, resistentes a las principales clases de antimicrobianos. Las canales con aspersión y el control $(10 \mathrm{~h})$ presentaron resistencia al meropenem. Conclusión: cuando la asperción duró 10 h, los aislados de E. coli presentaron mayor resistencia para una, dos y cuatro clases de antimicrobianos, es decir, fueron multirresistentes a los fármacos utilizados. Esto resalta la necesidad de monitorear el estado de salud durante todos los procesos de producción de carne.

Palabras clave: antibiótico; antimicrobiano; aspersión; canales; enterobactérias; Escherichia coli; multiresistencia; organismos multiresistentes; ovejas; resistencia bacteriana; resistencia antibacteriana; resistencia microbiana; resistencia multiple; sacrificio; salud pública.

\section{Resumo}

Antecedentes: bactérias multirresistentes presentes em alimentos de origem animal são motivo de preocupação e alerta na saúde humana e animal. Objetivo: verificar a resistência antimicrobiana em isolados de Escherichia coli de carcaças de ovinos pulverizadas ou não (4 e 10 horas) durante a refrigeração. Métodos: foram coletados trinta swabs de superfície em carcaças antes e após a última aspersão em dois abates. Em outubro do 2015, três carcaças aspergidas foram amostradas, três sem aspersão e uma carcaça para controle, por um período de 4 horas. Em julho de 2016 (2a coleta), o mesmo número de carcaças e tratamentos foram mantidos e o período de aspersão foi prolongado em 10 horas. As amostras coletadas foram isoladas e submetidas ao teste de susceptibilidade em 16 ( $1^{\mathrm{a}}$ coleta $)$ e 17 ( $2^{\mathrm{a}}$ coleta) antimicrobianos, respectivamente. Resultados: isolados de E. coli foram, em geral, resistentes às principais classes de antimicrobianos. As carcaças e o controle aspergidos (10 h) apresentaram resistência ao meropenem. Conclusão: quando a aspersão de água durou 10 horas, os isolados de E. coli apresentaram maior resistência antimicrobiana a uma, duas e quatro classes de antimicrobianos, o que é uma multirresistência aos fármacos testados. Isso alerta para a necessidade de monitorar os aspectos de saúde durante todos os processos de produção de carne.

Palavras-chave: abate; antibiótico; antimicrobiano; aspersão; carcaça; enterobactérias; Escherichia coli; ovelhas; resistência antimicrobiana; resistência bacteriana; resistência microbiana; organismo multirresistente; saúde pública. 


\section{Introduction}

Carcasschilling isanessentialsteptoguarantee hygiene, safety, shelf life, and overall appearance of meat. This process reduces the surface temperature of carcasses, preventing growth of unwanted and harmful bacteria (Ockerman and Basu, 2004). Some preventive techniques have been used in slaughterhouses to minimize the negative impact of chilling on carcasses. A common practice consists of spraying carcasses with water during chilling. However, according to Jones and Robertson (1988), and Strydom and Buys (1995), this practice may contribute to increased microbiological contamination under unfavorable conditions.

Antimicrobial resistance can be present in several processes within the food industry and, therefore, it is considered a complex multifactorial event (Santos, 2004). Environmental spread of multiresistant bacteria is pointed out by the World Health Organization as the main responsible for increased human deaths caused by antibiotic-resistant superbugs (O’Brien, 2002). Moreover, indiscriminate use of antimicrobials (Van Boeckel et al., 2015) also contributes to bacterial selection pressure, negatively affecting prevention and treatment of bacterial infections in humans and animals (Arslan and Eyi, 2010).

Growth-promoting antimicrobials are commonly used during several stages of intensive animal production. Nevertheless, the risks to human health outweigh the benefits provided by increased productivity (Oliver et al., 2010), especially involing pathogenic bacteria. Moreover, infections caused by multiresistant bacteria increase the risk of exposure to antimicrobial drugs, particularly considering their toxicological aspects (Safdar and Maki, 2002). This situation applies mainly to the treatment and prophylaxis of animal infectious diseases (Lerma et al., 2014).

Escherichia coli (E. coli) is commonly found in human and animal gut, but it can also affect health and lead to serious infections.
E. coli contamination in animal products generally occurs through accidental spillage of fecal material onto the carcasses during slaughter, particularly during the skinning and evisceration operations (Barros et al., 2007). However, cross-contamination occurs by manipulation, inadequate hygiene of facilities and/or equipment (Borch and Arinder, 2002).

This study aimed to assess resistance to antimicrobials in Escherichia coli isolates from sheep carcasses subjected to spray-chilling with water (4 and 10 hours) during cooling.

\section{Materials and methods}

\section{Ethical considerations}

Since this study involved only the sampling and analysis of microbiological materials from sheep carcasses in slaughterhouses, approval of an Ethics Committee on Animal Use was not mandatory. However, we ensure that the sheep were slaughtered within the welfare parameters regulated by the State Inspection Program of Santa Catarina, Brazil.

\section{Experimental Design}

Antimicrobial resistance of $E$. coli isolates was assessed by taking samples from randomly selected carcasses in a cold room. Samples were collected by swabbing both sides of each carcass during postmortem.

In October 2015, ten carcasses sprayed with chlorinated water $(1.5 \mathrm{ppm})$ for 4 consecutive hours, ten non-sprayed carcasses, and one control carcass were sampled for establishing the current health conditions at that time without the interference of those involved in the study. Therefore, these carcasses were neither included in the experiment nor manipulated by researchers, but only manipulated by the slaughterhouse employees.

In July 2016, the same sampling procedure and sample number of sprayed $(n=10)$ and nonsprayed carcass $(n=10)$ were taken. This time the carcasses were sprayed for 10 consecutive 
hours, and an additional carcass was added to the control group $(\mathrm{n}=2)$.

\section{Samples}

The sampling technique was an adaptation of the non-destructive method by NZFSA (2008), using sterile swabs. The swabs were taken by swabbing vertically, horizontally and diagonally over a $100 \mathrm{~cm}^{2}$ surface area delimited by a sterile template between the 12 and $13^{\text {th }}$ ribs on the left and right carcass halves (Figure 1). In the first sampling, seven carcasses were selected and distributed, as follows: three carcasses subjected to spraychilling using water (CWS $4 \mathrm{~h}, \mathrm{n}=36$ ), three non-sprayed carcasses (NSC $4 \mathrm{~h}, \mathrm{n}=36$ ) and one control carcass (COC $4 \mathrm{~h}, \mathrm{n}=12$ ), totaling 84 plates of $E$. coli isolates. In the second sampling, eight sprayed carcasses (CWS 10 $\mathrm{h}, \mathrm{n}=42$ ), three non-sprayed carcasses (NSC $10 \mathrm{~h}, \mathrm{n}=42$ ) and two control carcasses (COC $10 \mathrm{~h}, \mathrm{n}=28$ ) were selected, totaling 112 plates of $E$. coli isolates. All samples were packed in sterile Brain Heart Infusion (BHI) test tubes and immediately taken to the laboratory for processing and analysis.

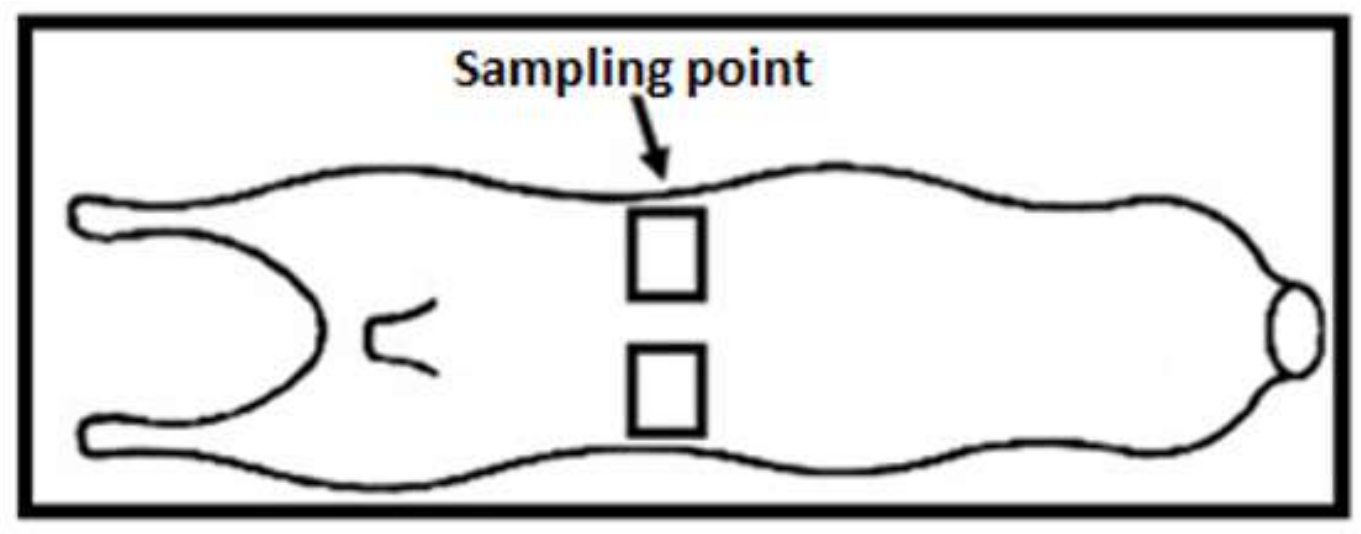

Figure 1. Carcass sampling areas.

\section{Isolation and identification of Escherichia coli}

The microbiological samples were homogenized in the laboratory. Then $1 \mathrm{~mL}$ was pipetted and incubated on six Petri dishes containing MacConkey agar medium (using the following serial dilutions: $10^{1}, 10^{2}, 10^{3}$, $10^{4}, 10^{5}$ and $10^{6} \mathrm{CFU} \mathrm{mL}^{-1}$ ) (KASVI, São José dos Pinhais, PR, Brazil). In the second step, the process was repeated using seven Petri dishes $\left(10^{1}, 10^{2}, 10^{3}, 10^{4}, 10^{5}\right.$, and $10^{6} \mathrm{CFU}$ $\mathrm{mL}^{-1}$ ). A total of 84 and 112 plates of E. coli isolates were obtained in the first and second samplings, respectively. Six characteristic $E$. coli colonies $\left(\mathrm{CFU} / \mathrm{cm}^{2}\right)$ were isolated from each plate using the dilutions indicated above. Samples were then incubated at $37^{\circ} \mathrm{C}$ for 18 24 hours according to the method described by Lenahan et al. (2009).

\section{Antimicrobial susceptibility test}

Samples were diluted in a $2 \mathrm{~mL}$ saline solution $(0.85 \%)$, and turbidity was estimated with the McFarland's scale. Subsequently, samples were incubated on Müller-Hinton agar medium (Oxoid Brasil Ltda, Pinheiros, SP, Brazil) to perform the susceptibility test using the disk diffusion method (Bauer et al., 1966).

Three groups of antimicrobials (Laborclin) were selected as standard antimicrobials. Group 1 from the first sampling (October 2015) consisted of amikacin $(30 \mu \mathrm{g})$, amoxicillin + clavulanate $(20 / 10 \mu \mathrm{g})$, ceftriaxone $(30 \mu \mathrm{g})$, ceftazidime $(30 \mu \mathrm{g})$, and gentamicin $(10 \mu \mathrm{g})$. This antimicrobial combination was aimed to confirm the presence of ESBL. Group 2 included nitrofurantoin $(300 \mu \mathrm{g})$, cefepime (30 
$\mu \mathrm{g})$, nalidixic acid $(30 \mu \mathrm{g})$, norfloxacin $(10 \mu \mathrm{g})$, and ciprofloxacin $(5 \mu \mathrm{g})$. Group 3 consisted of cephalothin $(30 \mu \mathrm{g})$, ampicillin $(20 \mu \mathrm{g})$, meropenem $(10 \mu \mathrm{g})$, sulfonamide $(300 \mu \mathrm{g})$, and tetracycline $(30 \mu \mathrm{g})$. The same antimicrobials used in the susceptibility test for the first sampling were used in the second sampling (July 2016), but chloramphenicol (30 $\mu \mathrm{g})$ and trimethoprim $(25 \mu \mathrm{g})$ were added to the second group. E. coli strain ATCC 25922 was used as a control. Reading and interpretation of the results were performed according to the Clinical and Laboratory Standards Institute (CLSI, 2015). Multiresistant isolates demonstrated resistance to three or more classes of antimicrobials (Magiorako et al., 2012). Determination of multiple antibiotic resistance (MAR) index was conducted according to the methodology described by Krumperman (1983).

\section{Statistical analysis}

A bivariate analysis using Pearson's correlation with $\mathrm{p}<0.05$ as significant was performed to test for heterogeneity or linear trend between treatments, considering the prevalence of bacterial resistance in each class of antimicrobials and their respective multidrug resistance. A 95\% confidence interval was considered for all tests. Additional calculations were performed using the Epi Info 7 software.

\section{Results}

The slaughtering process involves several critical points that could influence the results obtained in this study in terms of microbial contamination. Carcasses sprayed for 4 hours (CWS $4 \mathrm{~h}$ ) showed resistance to cephalothin $(94 \%, 34 / 36)$, nalidixic acid $(19 \%, 7 / 36)$, and sulfonamide $(25 \%, 9 / 36)$, as shown in Table 1.

Isolates from non-sprayed carcasses (NSC $4 \mathrm{~h}$ ) had the highest percentage of resistance to cephalothin $(97 \%, 35 / 36)$ and the lowest percentage of resistance to ampicillin + sulbactam $(17 \%, 6 / 36)$, amoxicillin + clavulanate $(11 \%$, $4 / 36)$, nitrofurantoin $(19 \%, 7 / 36)$, and nalidixic acid $(14 \%, 5 / 36)$. The following percentages of resistance were obtained for isolates from the control group (COC $4 \mathrm{~h}$ ): cephalothin ( $83 \%$, 10/12), ampicillin + sulbactam $(42 \%, 5 / 12)$, amoxicillin + clavulanic acid $(33 \%, 4 / 12)$. Resistance to nalidixic acid $(14 \%, 5 / 36)$ of isolates from non-sprayed carcasses was higher than $10 \%$, which warns public health risk, especially regarding the presence of residues in meat.

All 17 antimicrobials tested in E. coli isolates from carcasses sprayed for $10 \mathrm{~h}(10 \mathrm{~h}$ CWS) during the second sampling presented antimicrobial resistance higher than $10 \%$ (Table 1). Antimicrobials amikacin $(7 \%, 3 / 42)$, gentamicin $(4 \%, 2 / 42)$ ciprofloxacin $(0 \%)$, norfloxacin $(0 \%)$, and sulfonamide $(7 \%, 3 / 42)$ showed low resistance in carcasses of the treatment NSC $10 \mathrm{~h}$. The highest percentage of resistance was observed to cephalothin $(83 \%, 35 / 42)$, followed by ceftriaxone $(31 \%$, $13 / 42)$, ampicillin + sulbactam $(60 \%, 25 / 42)$, amoxicillin + clavulanate $(83 \%, 35 / 42)$, nitrofurantoin $(60 \%, 25 / 42)$, nalidixic acid $(31 \%, 13 / 42)$. Four out of 17 antimicrobials studied belong to the class of $\beta$-lactams. The control group (COC $10 \mathrm{~h}$ ) showed higher percentage of resistance to cephalothin $(18 \%$, $5 / 28)$, ceftazidime $(18 \%, 5 / 28)$, ceftriaxone $(14 \%, 4 / 28)$, meropenem $(14 \%, 4 / 28)$, nitrofurantoin $(18 \%, 5 / 28)$, nalidixic acid $(11 \%, 3 / 28)$, tetracycline $(11 \%, 3 / 28)$ and trimethoprim $(14 \%, 4 / 28)$. Resistance to meropenem was observed in spray-chilled carcasses $(19 \%, 8 / 42)$ and the control group $(14 \%, 4 / 28)$.

In E. coli isolates of the second sampling, the highest resistance to antimicrobial classes were detected for nitrofurans $(60,60$ and $17 \%)$, sulfonamides (7, 7 and $25 \%$ ) and $\beta$-lactams (24, 18 and $16 \%$ ) in sprayed, non-sprayed carcasses, and control group, respectively. When comparing the number of resistant antimicrobial classes between $E$. coli isolates of the first and second samplings (Figure 2), the most significant values were observed for carcasses sprayed and non-sprayed for 10 hours. 
Table 1. Percentage (\%) and absolute frequency (AF) of resistant $E$. coli isolates from sheep carcasses subjected to spray-chilling with water (CWS) and non-sprayed carcasses (NSC) at different sampling moments (2015 and 2016).

\begin{tabular}{|c|c|c|c|c|c|c|c|c|c|c|c|c|}
\hline \multicolumn{13}{|c|}{ Treatments } \\
\hline & \multicolumn{2}{|c|}{ CWS 4 h } & \multicolumn{2}{|c|}{ NSC $4 \mathrm{~h}$} & \multicolumn{2}{|c|}{ COC $4 \mathrm{~h}$} & \multicolumn{2}{|c|}{ CWS $10 \mathrm{~h}$} & \multicolumn{2}{|c|}{ NSC $10 \mathrm{~h}$} & \multicolumn{2}{|c|}{ COC $10 \mathrm{~h}$} \\
\hline \multicolumn{13}{|c|}{ Resistance } \\
\hline Antimicrobial & $\mathbf{A F}$ & $\%$ & $\mathbf{A F}$ & $\%$ & $\mathbf{A F}$ & $\%$ & $\mathbf{A F}$ & $\%$ & $\mathbf{A F}$ & $\%$ & $\mathbf{A F}$ & $\%$ \\
\hline AMI $(30 \mu \mathrm{g})$ & 0 & 0 & 0 & 0 & 0 & 0 & 3 & 7 & 1 & 2 & 1 & 3 \\
\hline GEN $(10 \mu \mathrm{g})$ & 0 & 0 & 0 & 0 & 0 & 0 & 2 & 4 & 0 & 0 & 1 & 3 \\
\hline CFL $(30 \mu \mathrm{g})$ & 34 & 94 & 35 & 97 & 10 & 83 & 36 & 86 & 35 & 83 & 5 & 18 \\
\hline CAZ $(30 \mu \mathrm{g})$ & 0 & 0 & 0 & 0 & 0 & 0 & 6 & 14 & 0 & 0 & 5 & 18 \\
\hline CRO $(30 \mu \mathrm{g})$ & 3 & 8 & 1 & 3 & 1 & 8 & 13 & 31 & 20 & 48 & 4 & 14 \\
\hline СРM $(30 \mu \mathrm{g})$ & 0 & 0 & 0 & 0 & 0 & 0 & 6 & 14 & 2 & 5 & 0 & 0 \\
\hline AMC $(20 / 10 \mu \mathrm{g})$ & 2 & 6 & 4 & 11 & 4 & 33 & 30 & 71 & 35 & 83 & 3 & 10 \\
\hline ASB $(20 \mu \mathrm{g})$ & 2 & 6 & 6 & 17 & 5 & 42 & 23 & 55 & 25 & 60 & 3 & 7 \\
\hline MER $(10 \mu \mathrm{g})$ & 0 & 0 & 0 & 0 & 0 & 0 & 8 & 19 & 1 & 2 & 4 & 14 \\
\hline NIT $(300 \mu \mathrm{g})$ & 2 & 6 & 7 & 9 & 4 & 33 & 25 & 60 & 25 & 0 & 5 & 8 \\
\hline CLO $(30 \mu \mathrm{g})$ & $(-)$ & $(-)$ & $(-)$ & $(-)$ & $(-)$ & $(-)$ & 2 & 5 & 4 & 9 & 1 & 4 \\
\hline NOR $(10 \mu \mathrm{g})$ & 0 & 0 & 0 & 0 & 0 & 0 & 0 & 0 & 0 & 0 & 0 & 0 \\
\hline $\mathrm{CIP}(5 \mu \mathrm{g})$ & 0 & 0 & 0 & 0 & 0 & 0 & 0 & 0 & 0 & 0 & 0 & 0 \\
\hline NAL $(30 \mu \mathrm{g})$ & 7 & 19 & 5 & 14 & 0 & 0 & 14 & 33 & 13 & 31 & 3 & 11 \\
\hline SUL $(300 \mu \mathrm{g})$ & 9 & 25 & 5 & 14 & 1 & 8 & 3 & 7 & 3 & 7 & 7 & 25 \\
\hline TET $(30 \mu \mathrm{g})$ & 2 & 6 & 0 & 0 & 0 & 0 & 6 & 14 & 1 & 2 & 3 & 11 \\
\hline TRI $(25 \mu \mathrm{g})$ & $(-)$ & $(-)$ & $(-)$ & $(-)$ & $(-)$ & $(-)$ & 24 & 57 & 16 & 38 & 4 & 141 \\
\hline
\end{tabular}

CWS 4 and $10 \mathrm{~h}=$ carcasses subjected to spray-chilling using water for 4 and $10 \mathrm{~h}$; NSC 4 and $10 \mathrm{~h}=$ non-sprayed carcasses; COC 4 and $10 \mathrm{~h}=$ control carcass; $\mathrm{AF}=$ absolute frequency; $(-)=$ antimicrobial not tested; $\mathrm{AMI}=$ amikacin; $\mathrm{GEN}=$ gentamicin; $\mathrm{CFL}=$ cephalotin; $\mathrm{CAZ}=$ ceftazidime $\mathrm{CRO}=$ ceftriaxone $\mathrm{CPM}=$ cefepime; $\mathrm{AMC}=$ amoxicillin + clavulanate $\mathrm{ASB}=$ amoxicillin + subactam; $\mathrm{MER}$ $=$ meropenem; $\mathrm{NIT}=$ nitrofurantoin; $\mathrm{CLO}=$ chloramphenicol; $\mathrm{NOR}=$ norfloxacin; $\mathrm{CIP}=$ ciprofloxacin; $\mathrm{NAL}=$ nalidixic acid; $\mathrm{SUL}$ $=$ sulfonamide; $\mathrm{TET}=$ tetracycline; $\mathrm{TRI}=$ trimethoprim.

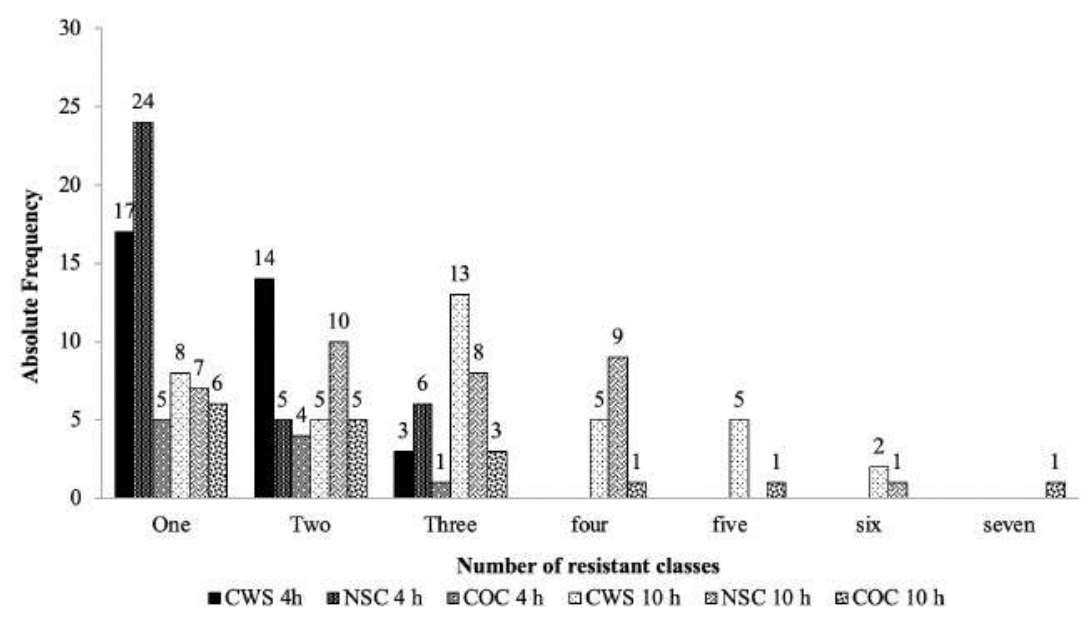

Figure 2. Absolute frequency of antimicrobial-resistant E. coli isolates per class tested in the first (October 2015) and second sampling (July 2016). 
The multiple antibiotic resistance (MAR) indexes of spray-chilled, non-sprayed, and control carcasses were $0.3,0.1$, and 0.1 , respectively. These values reinforce concerns regarding cross-contamination during the manipulation of animal products. Relative to samplings periods, the values were statistically significant (Table 2) $(p<0.05)$ only when comparing NSC $4 \mathrm{~h} \times \mathrm{NSC} 10 \mathrm{~h}(\mathrm{p}=0.006)$ for one class, CWS $4 \mathrm{~h}$ x CWS $10 \mathrm{~h}(\mathrm{p}=0.0577)$ for two classes and NSC $4 \mathrm{~h}$ x NSC $10 \mathrm{~h}$ $(p=0.0211)$ for four classes, in which spraychilled carcasses were more multiresistant. No significant results were found for comparisons within treatments.

Table 2. Statistical significance of antimicrobial-resistant classes tested in E. coli isolates from sheep carcasses subjected to spray-chilling with water in the postmortem period.

\begin{tabular}{|c|c|c|c|c|c|c|c|c|c|}
\hline & & & \multicolumn{7}{|c|}{ Antimicrobial Classes } \\
\hline \multicolumn{3}{|c|}{ Treatments } & One & Two & Three & Four & Five & Six & Seven \\
\hline CWS 4 h & $\mathrm{x}$ & $\mathrm{NSC} 4 \mathrm{~h}$ & NS & NS & NS & NS & NS & NS & NS \\
\hline CWS $4 \mathrm{~h}$ & $\mathrm{x}$ & $\mathrm{COC} 4 \mathrm{~h}$ & NS & NS & NS & NS & NS & NS & NS \\
\hline $\mathrm{NSC} 4 \mathrm{~h}$ & $\mathrm{x}$ & $\mathrm{COC} 4 \mathrm{~h}$ & NS & NS & NS & NS & NS & NS & NS \\
\hline CWS $4 \mathrm{~h}$ & $\mathrm{x}$ & CWS $10 \mathrm{~h}$ & NS & $0.0577^{*}$ & NS & NS & NS & NS & NS \\
\hline $\mathrm{NSC} 4 \mathrm{~h}$ & $\mathrm{x}$ & NSC $10 \mathrm{~h}$ & $0.006^{*}$ & NS & NS & $0.0211^{*}$ & NS & NS & NS \\
\hline $\mathrm{CCO} 4 \mathrm{~h}$ & $\mathrm{x}$ & $\mathrm{COC} 10 \mathrm{~h}$ & NS & NS & NS & NS & NS & NS & NS \\
\hline CWS $10 \mathrm{~h}$ & $\mathrm{x}$ & CWS $10 \mathrm{~h}$ & NS & NS & NS & NS & NS & NS & NS \\
\hline CWS $10 \mathrm{~h}$ & $\mathrm{x}$ & $\mathrm{COC} 10 \mathrm{~h}$ & NS & NS & NS & NS & NS & NS & NS \\
\hline $\mathrm{NSC} 10 \mathrm{~h}$ & $\mathrm{x}$ & $\mathrm{COC} 10 \mathrm{~h}$ & NS & NS & NS & NS & NS & NS & NS \\
\hline
\end{tabular}

$\mathrm{CWS}=$ Carcasses subjected to spray-chilling using water for 4 and $10 \mathrm{~h}$; NSC $=$ Non-sprayed carcasses; COC 4 and $10 \mathrm{~h}=\mathrm{Control}$ carcass, NS $=$ not significant, $*$ Significance declared at $\mathrm{p}<0.05$.

\section{Discussion}

We found high levels of antimicrobial resistance in carcasses subjected to long spraychilling with water. Regardless of treatment, it is noteworthy that antimicrobial resistance was significant for most antimicrobials, mainly for $\beta$-lactams. A previous study showed that antimicrobial resistance might involve three mechanisms: decreasedaccumulationofthedrugs by the cell, hydrolysis of antimicrobials, and/or reductions in drug affinity due to alterations in binding proteins (Miró et al., 1994). In addition to the ability of bacteria to produce $\beta$-lactamases, no extended-spectrum $\beta$-lactamases (ESBL) were found among $E$. coli isolates in this study.

In the first sampling, carcasses sprayed for 4 hours were resistant to $\beta$-lactams, quinolones, and sulfonamides, while non-sprayed carcasses showed resistance to $\beta$-lactams, quinolones, and nitrofurans. According to Phillips et al. (2004), antimicrobials can select resistant mutant bacterial strains through resistance transferred from other bacteria. The resistance to quinolone in gram-negative bacilli is mainly attributed to gene mutations that encode quinolone targets and alterations in external membrane proteins or efflux pumps (Strahilevitz et al., 2009; Lindgren et al., 2003). Overall, these results corroborate previous studies conducted by Sáenz et al. (2001) and Dontorou et al. (2003), which indicate resistance to the main classes of antimicrobials in $E$. coli isolates from animal products.

Studies by Rahamathulla et al. (2016) showed that resistance to meropenem is an increasing public health problem because this antibiotic is one of the last resources for the treatment of infections in hospitals. Rasmussen et al. (1996) reported that this is associated with genes encoding carbapenemases on plasmids or 
transposons in carbapenem-resistant bacteria. In $E$. coli, these genes are responsible for resistance to carbapenems due to the presence of an outer membrane protein deficiency and expression of plasmid-mediated class $\mathrm{C}$ betalactamase gene (Stapleton et al., 1999). The $E$. coli isolates from the control carcasses showed resistance to meropenem, possibly due to crosscontamination of bacteria with the resistance gene for this carbapenem during slaughter.

The present study indicated that $E$. coli isolates from carcasses subjected to spray-chilling with water had greater antimicrobial resistance, especially in carcasses sprayed for $10 \mathrm{~h}$, even with the recommended chlorine level. Longer spraychilling time facilitated the dispersion of bacteria on carcasses, which may increase contamination of carcass surfaces. Moreover, spray-chilling increased both colonization of bacteria and their survival under cooling conditions.

\section{Declarations}

\section{Acknowledgments}

The authors wish to acknowledge support from Departamento de Zootecnia, Universidade do Estado de Santa Catarina, Brazil.

\section{Funding}

This study was funded by Conselho Nacional de Ciência e Tecnologia (CNPQ - Process n. 424795/2016-7, CNPq Public notice 01/2016) with support from Universidade do Estado de Santa Catarina (UDESC), Brazil.

\section{Conflicts of interest}

The authors declare they have no conflicts of interest with regard to the work presented in this report.

\section{Author contributions}

All authors contributed extensively to all aspects of this work, including the conception and design of the study, implementation, data analysis, and manuscript writing.

\section{References}

Arslan S, Eyi A. Occurrence and microbial resistance profiles of Salmonella species in retail meat products. J Food Protect 2010; 73(9):1613-1617. DOI: https://doi.org/10.4315/0362-028X-73.9.1613

Barros MFA, Nero LA, Monteiro AA, Beloti $\mathrm{V}$. Identification of main contamination points by hygiene indicator microorganisms in beef processing plants. Ciênc Tecnol Aliment 2007; 27(4):856-862. DOI: http://dx.doi.org/10.1590/S0101-20612007000400028

Bauer AW, Kirby WMM, Sherris JC, Turck M. Antibiotic susceptibility testing by a standardized single disk method. Amer J Clin Pathol 1966; 45(4):493-496. DOI: https://doi.org/10.1093/ajcp/45.4 ts.493

Borch E, Arinder P. Bacteriological safety issues in beefandready-to-eatmeatproducts, aswellascontrol measures. Meat Sci 2002; 62(3):381-390. DOI: https://doi.org/10.1016/S0309-1740(02)00125-0

CLSI. Performance standards for antimicrobial disk susceptibility tests; approved standard - eleventh edition. Wayne, PA: Clinical and Laboratory Standards Institute, 2015. DOI: https://clsi.org/media/1631/m02a12 sample.pdf

Dontorou C, Papadopoulou C, Filioussis G, Economou V, Apostolou I, Zakkas GA, Salamoura A, Kansouzidou A, Levidiotou S. Isolation of Escherichia coli O157:H7 from foods in Greece. Int J Antimicrob Ag 2003; 82(3):273-279. DOI: https://doi.org/10.1016/S0168-1605(02)00313-6

Jones SDM, Robertson WM. The effects of spray-chilling carcasses on shrinkage and quality of beef. Meat Sci1988; 24(3):177-188. DOI: https://doi.org/10.1016/0309-1740(88)90076-9

Krumperman PH. Multiple antibiotic resistance indexing of Escherichia coli to identify high-risk sources of fecal contamination of foods. Appl Environ Microbiol 1983; 46(1):165-1670. DOI: https://doi.org/0099-2240/83/070165-06\$02.00/0 
Lenahan M, Crowley H, O'Brien SB, Byrne C, Sweeney T, Sheridan JJ. The potential use of chilling to control the growth of Enterobacteriaceae on porcine carcasses and the incidence of $E$. coli $\mathrm{O} 157: \mathrm{H} 7$ in pigs. J Appl Microbiol 2009; 106(5):1512-1520. DOI: https://doi.org/10.1111/j.1365-2672.2008.04112.x

Lerma LL, Benomar N, Knapp CW, Galeote DC, Gálvez A, Abriouel, HLC. Diversity, distribution and quantification of antibiotic resistance genes in goat and lamb slaughterhouse surfaces and meat products. Plos One 2014; 9(12):1-17. DOI: https://doi.org/10.1371/journal.pone.0114252

Lindgren PK, Karlsson Å, Hughes D. Mutation rate and evolution of fluoroquinolone resistance in Escherichia coli isolates from patients with urinary tract infections. Antimicrob Agents Ch 2003; 47(10):3222-3232. DOI: https://doi.org/10.1128/AAC.47.10.3222-3232.2003

Magiorako AP, Srinivasan A, Carey RB, Carmeli Y, Falagas ME, Giske CG, Harbarth S, Hindler JF, Kahlmeter G, Olsson-Liljequist B, Paterson DL, Arroz LB, Stelling J, Struelens MJ, Vatopoulos A, Weber JT, Monnet DL. Multidrug-resistant, extensively drug-resistant and pandrug-resistant bacteria: an international expert proposal for interim standard definitions for acquired resistance. Clin Microbiol Infect 2012; 18(3):268-281. DOI: https://doi.org/10.1111/j.1469-0691.2011.03570.x

Miró E, Sabaté M, Navarro F, Vergés C, Aliaga R, Mirelis B, Prats G. $\beta$-lactamases involved in resistance to broad-spectrum cephalosporins in Escherichia coli and Klebsiella spp. Clinical isolates collected between 1994 and 1996, in Barcelona (Spain). J Antimicrob Chemother 2002; 49(6):989-997. DOI: https://doi.org/10.1093/jac/dkf057

NZFSA. Sampling DRAFT Schedule 1: Technical procedures for the national microbiological database. 2008;50-60. URL: https://www. nzfsa.govt.nz/animalproducts/publications/ manualsguides/nmd/nmd-tech-proced/ checksheets/ nmdchecklistguidelines.pdf
O'Brien TF. Emergence, spread, and environmental effect of antimicrobial resistance: How use of an antimicrobial anywhere can increase resistance to any antimicrobial anywhere else. Clin Infect Dis 2002; 34(3):78-84. DOI: https://doi.org/10.1086/340244

Ockerman HW, Basu L. Carcass chilling and boning. In: J. Werner Klinth (1 Ed.), Encyclopedia of Meat Sciences: Oxford: Elsevier; 2004;148-149.

Oliver SP, Murinda SE, Jayarao BM. Impact of antibiotic use in adult dairy cows on antimicrobial resistance of veterinary and human pathogens: A comprehensive review. Foodborne Pathog Dis 2011; 8(3):337-355. DOI: https://doi.org/10.1089/fpd.2010.0730

Phillips I, Casewell M, Cox T, De Groot B, Friis C, Jones R, Nightingale C, Preston R, Waddell J. Does the use of antibiotics in food animals pose a risk to human health? A critical review of published data. J Antimicrob Chemother 2004; 23(1):28-52. DOI: https://doi.org/10.1093/jac/dkg483

Rahamathulla MP, Harish BN, Mataseje L, Mulvey MR. Carbapenem resistance mechanisms among blood isolates of Klebsiella pneumoniae and Escherichia coli. Afr J Microbiol Res 2016; 10(2):45-53. DOI: https://doi.org/10.5897/AJMR2015.7802

Rasmussen BA, Bush K, Keeney D, Yang Y, Hare R, O'Gara C, Medeiros AA. Characterization of IMI-1 $\beta$-Lactamase, a Class A Carbapenem Hydrolyzing Enzyme from Enterobacter cloacae. Antimicrob Agents Ch 1996; 40(3):2080-2086. DOI: https://doi.org/10.1128/AAC.40.9.2080

Sáenz Y, Zarazaga M, Briñas L, Lantero M, Ruiz-Larrea F, Torres C. Antibiotic resistance in Escherichia coli isolates obtained from animals, foods and humans in Spain. Int $\mathbf{J}$ Antimicrob Ag 2001; 18(4):353-358. DOI: https://doi.org/10.1016/S0924-8579(01)00422-8

Safdar N, Maki DG. The commonality of risk factors for nosocomial colonization and infection with antimicrobial-resistant Staphylococcus aureus, Enterococcus, gram-negative bacilli, 
Clostridium difficile, and Candida. Ann Intern Med 2002; 136(11):834-844. DOI: https://doi.org/10.7326/0003-4819-136-11$\underline{200206040-00013}$

Santos NQ. Bacterial resistance in the context of hospital infection. Texto Contexto Enferm 2004; 13(1):64-70. DOI: http://dx.doi.org/10.1590/S0104-07072004000500007

Stapleton PD, Shannon KP, French GL. Carbapenem resistance in Escherichia coli associated with plasmid-determined CMY-4 $\beta$-Lactamase production and loss of an outer membrane protein. Antimicrob Agents Ch 1999; 43 (5):1206-1210. DOI: https://doi.org 10.1128/AAC.43.5.1206
Strahilevitz J, Jacoby GA, Hooper DC, Robicsek A. Plasmid-mediated quinolone resistance: a multifaceted threat. Clin Microbiol Rev 2009; 22(4):4664-6891. DOI: https://doi.org/10.1128/CMR.00016-09

Strydom PE, Buys EM. The effects of spraychilling on carcass mass loss and surface associated bacteriology. Meat Sci 1995; 39(2):265-276. DOI: https://doi.org/10.1016/0309-1740(88)90076-9

Van Boeckel TP, Brower C, Gilbert M, Grenfella BT, Levina SA, Robinsoni TP, Teillant A, Laxminarayan R. Global trends in antimicrobial use in food animals. PNAS 2015; 112 (18):5649-5654. DOI: https://doi.org/10.1073/pnas.1503141112 